\title{
Journal of the SOCIETY OF DAIRY TECHNOLOGY
}

\section{Contents}

General Meeting

Whither Dairying? by Sir James Barker

Spring Conference

Modern Cheese Packaging by B. E. Gray

Meeting Present and Future Requirements of Regulations Governing Milk and Dairy Products in the Netherlands by $J . M$. van der Bas

Use of Semi-Automatic Instruments for Process and Product Control in the Dairy-Food Industry - Routine Assessment of Total Protein and Heat Treatment in Milk Powder by Dye Binding by T.C.A.McGann, J.A. $O$ 'Connell and Rosario McFeely
Vol 28 No 1 January 1975

Personalia

Conference

Subject: Dairy in the EEC.

Production and Marketing of Milk Products in the EEC by B.H.B. Dickinson

Vegetable Proteins, with Particular Reference to Soybean Protein by J.S. Pagington

Obituary

Thirty-first Annual General Meeting

The Society's Committees

Section Notes

Summaries of Papers in this Issue

Published quarterly (January, April, July and October) by The Society of Dairy Technology, $172 \mathrm{~A}$, Ealing Road, Wembley, Middlesex, HA0 4QD.

Subscription Rates: $£ 8.00$ per volume of four issues (U.S.A. and Canada $\$ 20.00$ ). Single issues £2.50. All enquiries to The Secretary, at the above address. 


\section{DIRECTIONS TO CONTRIBUTORS}

\section{GENERAL}

Manuscripts should be sent to Dr M. E. Sharpe (The Journal of Dairy Research), National Institute for Research in Dairying, Shinfield, Reading, RG2 9AT, England. Submission of a paper will be held to imply that it reports unpublished original work, that it is not under consideration for publication elsewhere, and that if accepted for the Journal it will not be published elsewhere in any language, without the consent of the Editors.

\section{FORM OF PAPERS}

The author should follow these directions carefully, and consult a current issue of the Journal for guidance on details of typographical and other conventions.

Every paper should be headed with its title, the names and initials of the authors (women supplying one given name) and the name and address of the laboratory where the work was done.

Papers should be in English, using the spelling of the Shorter Oxford English Dictionary. They should be typed with double spacing. on one side only of the sheets, and with ample margins for editorial annotations.

Papers should in general be divided into the following parts in the order indicated: $(a)$ Summary, brief and self-contained: (b) Introductory paragraphs, briefly explaining the object of the work but without giving an extensive account of the literature: $(c)$ Experimental or Methods; $(d)$ Results: $(e)$ Discussion and Conclusions; $(f)$ Acknowledgements without a heading: $(\mathrm{g})$ References. With some types of material headings other than $(c),(d)$ and (e) may be preferable.

The use of footnotes should be avoided if possible. Underlining should be used only to indicate italics. Proper nouns, including trade names, should be given a capital initial letter. Wherever possible numerals should be used unless this leads to ambiguity. The typescript should carry the name and address of the person to whom the proofs are to be sent, and give a shortened version of the paper's title, not exceeding 45 letters and spaces, suitable for a running title in the Journal.

\section{TABLES}

Tables should be numbered and should carry headings describing their content. They should be comprehensible without reference to the text. They should be typed on separate sheets and their approximate positions in the text indicated. To minimize the cost of printing, the number and size of tables should be kept to an absolute minimum.

\section{ILLUSTRATIONS}

Line drawings, which must be originals, should be numbered as Figures and photographs as Plates, in Arabic numerals. Drawings should be in Indian ink, on Bristol board or cartridge paper. However, a technique which may be more convenient to authors is to use a double-sized piece of tracing paper, or translucent graph paper faintly lined in blue or grey, folded down the centre with the drawing on one half and the other half acting as a flyleaf.

Attached to every figure and plate there should be a translucent flyleaf cover on the outside of which should be written legibly: $(a)$ title of paper and name of author; (b) figure or plate number and explanatory legend; (c) the figures and lettering, which are intended to appear on the finished block, in the correct positions relative to the drawing underneath. Each paper should have a separate typed sheet listing figure and plate numbers with their legends, and the approximate positions of illustrations should be indicated in the text.

The photographs and diagrams should be about twice the size of the finished block and not larger overall than the sheets on which the paper itself is typed. For a figure measuring $250 \mathrm{~mm} \times 150 \mathrm{~mm}$ all lines, axes and curves should be $0.4 \mathrm{~mm}$ thick, thus Graph symbols in order of preference are $\bigcirc, \triangle \boldsymbol{\Delta}$, $\square \mathbf{v}, \times+$, and for a $250 \mathrm{~mm} \times 150 \mathrm{~mm}$ graph the circles should be $3 \mathrm{~mm}$ in diam. The triangles should be equilateral of $3 \mathrm{~mm}$ side, and the squares also of $3 \mathrm{~mm}$ side. The crosses should have lines $3 \mathrm{~mm}$ long at right angles. Scale marks on the axes should be on the inner side of each axis and should be $3 \mathrm{~mm}$ long.

\section{SHORT COMMUNICATIONS}

Short communications or notes of not more than 2000 words, containing only one Table or Figure, and without a summary will also be published.

\section{REFERENCES}

In the text, references should be quoted by whichever of the following ways is appropriate: Arnold \& Harnard (1900); Arnold \& Barnard (1900a); Arnold \& Barnard $(1900 a, b)$ : (Arnold \& Barnard, 1900). Give all the surnames of 3 authors at the first mention, but in subsequent citations and in all cases where there are more than 3 authors give only the first surname (e.g. Brown et al.) provided that there is no possible ambiguity.

References should be listed alphabetically at the end of the paper. Titles of journals should be given in full, authors' initials should be included, and each reference should be punctuated in the typescript thus: Arnold, T. B., Barnard, R. N. \& Compound, P. J. (1900). Journal of Dairy Research 18, 158. References to books should include names of authors, year of publication, title, names of editors, town of publication and name of publisher in that order, thus: Arnold, T. B. (1900). Dairying. London: Brown and Chester.

It is the duty of the author to check all references.

\section{UNITS, SYMBOLS AND ABBREVIATIONS}

S1 units must be used, as explained in British Standards Institution publication PD 5686:1972, The use of SI units. Until SI units are widely understood, it is permissible to give the equivalent value in other units in parenthesis. Symbols and abbreviations used are those of British Standard 1991: Part 1: 1967. Letter Symbols, Signs and Abbreviations.

\section{DESCRIPTIONS OF SOLUTIONS}

Normality and molarity should be indicated thus: $\mathrm{N}-\mathrm{HCl}, 0.1 \mathrm{M}-\mathrm{NaH}_{2} \mathrm{PO}_{4}$. The term ${ }^{\circ} \%$ ' means $\mathrm{g} / 100 \mathrm{~g}$ solution. For $\mathrm{ml} / 100 \mathrm{ml}$ solution the term ${ }^{\circ} \circ(\mathrm{v} / \mathrm{v})^{\circ}$ should be used and for $\mathrm{g} / 100 \mathrm{ml}$ solution the correct abbreviation is ${ }^{\circ} \circ(\mathrm{w} / \mathrm{v})^{\circ}$.

\section{REPRINTS}

Order forms giving quotations for reprints are sent to authors with their proofs. 


\section{CONTENTS}

Interspecies study on the effect of perphenazine on milk yield and composition J. SHANI (MISHKINSKY), A. T. COWIE and W. H. BROSTER

pages $1-9$

Influence of sympathomimetic drugs on the motility of bovine teat

muscles

G. PEETERS and R. DE BRUYCKER

Organochlorine content of milks, dairy products and animal feed

ingredients: Ireland 1971-1972

W. K. DOWNEY, M. P. FLYNN and S. A. AHERNE

Proteolysis detection in milk. III. Relationships between bacterial popula-

tions, tyrosine value and organoleptic quality during extended cold

storage of milk and cream

H. S. JUFFS

Some physico-chemical properties of porcine milk

M. C. T. HOYNES and P. F. FOX

$43-56$

Studies on the heat stability of milk protein. 1I. Effect of exposing milk to light

A. W. M. SWEETSUR and J. C. D. WHITE

Studies on the heat stability of milk protein. III. Effect of heat-induced acidity in milk

A. W. M. SWEETSUR and J. C. D. WHITE

Properties of aseptically packed ultra-high-temperature milk. III. Formation of polymerized protein during storage at various temperatures

A. T. ANDREWS

Separation of the glycopeptides released by the action of rennin on whole milk

G. SIMPSON, G. SINKINSON and J. V. WHEELOCK

$101-109$

Proteolysis in Cheddar cheese: influence of the rate of acid production during manufacture

R. B. O'KEEFFE, P. F. FOX and C. DALY

The nature of the stimulation of the growth of Streptococcus lactis by yeast extract

J. SELBy SMith, A. J. HiLLieR, G. J. LEes and G. R. JAGO

Citrate utilization in milk by Leuconostoc cremoris and Streptococcus diacetilactis

T. M. COGAN

$139-146$

Peptidase activities in Group N streptococci

L. MOU, J. J. SULLIVAN and G. R. JAGO

$147-155$

Preparation and properties of $\alpha_{2}$-casein from buffalo's milk

M. H. ABD EL-SALAM

$157-162$

Preparation and properties of $\beta$-casein from buffalo's milk

M. H. ABD EL-SALAM and S. EL-SHIBINY

$163-167$

A study of the properties of dissociated bovine casein micelles

L. K. CREAMER and G. P. BERRY

$169-183$

Autoxidation in milk rich in linoleic acid. I. An objective method for measuring autoxidation and evaluating antioxidants

G. S. SIDHU, M. A. BROWN and A. R. JOHNSON

Reviews of the progress of Dairy Science.

Water-soluble vitamins in milk and milk products

M. E. GREGORY

$197-216$

c Proprietors of The Journal of Dairy Research, 1975 